$\xi=-$ 圆

\title{
A Crital Review of Islamic and Conventional Banking in Digital Era: A Case of Pakistan
}

\author{
Dr. Muzaffar Asad, Israr Ahmad, Syed Hussain Haider, Dr. Rabia Salman \\ Assistant Professor, Faculty of Management and Social Sciences, Capital University of Science and Technology Islamabad \\ muzaffar.asad@cust.edu.pk \\ Ph.D. Scholar School of Business Management University Utara Malaysia \\ chaudhryisrar@gmail.com \\ Chief Strategy Officer Akhuwat, Lahore School of Business Management University Utara Malaysia \\ aarabiaa@gmail.com
}

\begin{abstract}
Islamic banking is growing at a fast pace in economies which are considered as the champions of entrepreneurship and counter interestbased monetary system. Currently, Islamic banks have touched $\$ 1$ trillion and is rising around at $20 \%$ yearly. However, this rapid growth is not limited to the Muslim countries but commodities of Islamic institutions are obtaining reputation in non-Muslim countries. The purpose of this study is to understand the main differences in Islamic and conventional banking in Pakistan on the basis of cost and benefit analysis, comparison of lending structure, and comparison of risk management especially in the context of current digital era. The methodology followed in the paper is based on the review of literature and particularly the banking practices in Pakistan. In this study, it has been analyzed that how a system made by Muslim economists long ago has become a powerful reality. This study inspects the upright addendum of Islamic banking and compare it to conventional banking. Effects of the inspection are positive as the productivity and success of Islamic banks is better than that of non-Islamic banks even in current digital economies. It is useful for the practitioners and policy makers to seek guidance for strengthening of the system.
\end{abstract}

Keywords Islamic banking, conventional banking, digital economy, comparison, risk management.

\section{Introduction}

Before comparing Islamic and conventional banking, it is better understand banking system of Pakistan. At the time of independence, Pakistan contains practically no businesses, however, banking services were provided here (Ahmad, Malik, \& Humayoun, 2010). Newly established country, running short of capital, was in a difficulty to incorporate new banking system. In August 1947, a significant number of banks closed their branches, because head offices of those branches were in India, so most of their staff shifted to India (Rammal \& Parker, 2013). In result of that entire incident only 81 branches out of 487 were left till 30th June 1948. As a result, State Bank of Pakistan (SBP) was established on 1 July 1948 and started operating as the central bank under SBP Act 1956 and was also responsible for the National Credit Policy (Ake, 1975). SBP has significant active roles i.e. guardian of cash reserves of scheduled banks, guardian of foreign reserves, rediscounting bills of exchange, state allowance, payment and transferal, and directing financial policy for constancy of banking sector (Gafoor, 1995).

Similarly, total investments of scheduled banks resulted the growth of 95 billion rupees during financial year 2008 (Azmi, 2013). Financial sector of Pakistan is experiencing fast-paced owing to technology advancement where new competitors are acquiring administration of foreign banks (Mobarek \& Kalonov, 2013). Recently, banking sector has increased immensely. Therefore, there are dozens of scheduled and investment banks adminis- trating in the country and scheduled banks performed well since their incorporation hence they increase their profits because of high deposits. Apart from getting high and efficient non-financial profits from restructuring and policies of banking sector, financial profits have been gained through high interest rates (Ansari \& Rehman, 2013).

Islamic banking was introduced mainly in Islamic world forty years ago (Ali, 2014). In the beginning, private initiators incorporated Islamic and financial institutions in numerous parts around the world including non-Muslim countries and now they are more than hundred (Islam \& Rahman, 2017). Afterwards, experts tried to convert the entire financial system to Islamic rules and regulations in Muslim countries i.e. Sudan, Iran, Malaysia, and Pakistan. Thus, experiments have been operating since more than two decades. Nevertheless, the financial administration is mainly affected by banking sector. In fact, there are few non-financial institutions in Pakistan (Hong \& Yogo, 2012). Steps to Islamization of Banking system were started by SBP in 1977-78 (Lee \& Ullah, 2008). Different bankers were ordered to give accommodations of finance for government operations regarding investment of money as well as on sale of deferred payments with a profit on buying price (Dietsch \& Lozano-Vivas, 2000). Since 1 July 1982, scheduled banks were permitted to give money to meet the needs of working capital of industry under Musharakah. SBP issued indepth procedure in December 2001 for incorporation of Islamic banking in private sector and Al-Meezan Investment Bank was declared as first Islamic bank by taking license from SBP in January 2002 and started its operations on 20th March 2002 (Mahmood, 2007). SBP permitted different banks to operate on 
the basis of Islamic principles. Moreover, SBP incorporated commission to transform interest-based system to Shri'a mode (Gafoor, 1995).

Commercial or conventional banks are totally based on man-made rules and regulations and purpose is to increase profitability (Ullah, 2016). The vital purpose of these banks is to lend money at high rate of interest and borrow at low rate, the difference is the profit of the banks. Operations of Islamic banks are based on markupfree banking but conventional banks followed profit-based tactics and rules. Islamic banking system restricts interest but conventional follow maximization of profits (Jalbani \& Shaikh, 2009). Conventional banks are more than Islamic banks but avoid to share their profitability (Beck, Demirgüç-Kunt, \& Merrouche, 2013). Since 15 September 2003, SBP establish Islamic department to assist Islamic banking and play role in economic, financial and social activities (Lal \& Snehal, 2008). Government also started Ijara Sukuk to improve its money market sector in Pakistan (Akhter, Islamic Banking, 2008). However, despite all the efforts and initiatives it has been observed that Islamic banking has not been flourished in the country till today (Shahid, Rehman, \& Niazi, 2010). Islamic banks share their profits and losses with their respective depositors (Samad, 2004). Hence, this sharing makes Islamic system better than conventional ones, however, in Pakistan Islamic banking was started years back but still it has failed to mature (Shahid, Rehman, \& Niazi, 2010). Therefore, objective of this study is to compare Islamic and conventional banking system to understand that why the pace of growth of Islamic Banking is low in Pakistan.

\section{Results}

The literature review mainly focused on comparing conventional and Islamic banking based on cost benefit analysis, lending structure and bank insolvency, and risk management practices. The major element of Islamic banking is the restriction of Riba (interest). The contradiction opposes to Riba that money is not a commodity and surplus can be gained only on commodities instead of money. As Holy Quran tells us that when barter system was practiced, generally six commodities namely Gold, Silver, Dates, Wheat, Salt, and Barley were traded. Traders charge extra value as compared to value landed to borrower. Holy Quran termed the name of this profit as Riba or Usuary which in today's conventional banking is termed as Interest. The current literature mainly focused on three things the first is cost and profit analysis of conventional and Islamic banking, comparison of lending structure and bank insolvency, and comparison of risk management practices between conventional and Islamic banks.

\section{Cost and Profit Analysis}

Over last ten years, some studies on cost-benefit efficiency in aggressive bank markets of the Europe and North America. There have some researches on countries in change. However, research on banking efficiency in developing Islamic countries looks vague but few studies highlighted that macroeconomic environment presents an attractive outcome of expense preference behavior (Aliyu \& Yusof, 2016). The size of the bank matters against the economies of scale in terms of Islamic banking as the operations enhance, economies of scale are lost (Miah \& Uddin, 2017). But on the other hand, Abdul-Majid, Saal, and Battisti (2010) contradicted and argued that Islamic banks can enhance their efficiency by enhancing their operations. Analysis of cost efficiency highlighted that $68 \%$ banks are cost efficient and reason behind the rest of $32 \%$ inefficiency is managerial and regulatory inefficiency. Outcomes revealed that smaller systems are more efficient than larger one, thus, profitability of the banks is directly related to the efficiency index. Likewise, Srairi, Abderrazek, and Anal (2010) estimated the technical efficiency of 8 banks 1994-1999 by using an approach called stochastic cost frontier. So, researchers follow inter-mediation approach and concluded that relative cost efficiency of entire banks is $91 \%$. It has been found that there are some banks that produce earning assets from their constants returns, therefore, they gain less from growing scale of productivity, by amalgamating with rest of banks to reduce hurdle through technical efficiency. Finally, this is concluded that larger size of banks, higher capital ratio, and immense profitability is only depending on efficiency.

\section{Comparison of Lending Structure and Bank Insolvency Risk}

Studies on factors of bank risk exposures per se are very narrow. So far, very few studies have examined the elements touching financial institutes risk exposure. In lending structure it has been observed that Islamic banks are more solid in terms of short-term solvency but no such difference exists as far as the long-term stability is concerned (Miah \& Uddin, 2017). Islamic banks allocate a greater share of their assets to lending activities compared to conventional banks (Ariss, 2010). The current research inspects the impact of loaning structure on liquidation risk coverage for both the conventional and Islamic banking system. It was recognized to carry out commercial banks actions that are Syariah compliant and it is organized to operate beside with the conventional banks. The Islamic banking system windows operate and lending using the services of conventional banks.

Comparison of Risk Management Practices between Conventional and Islamic Banks

In the 21st century Islamic banking system with high opinion to risk management was examined by Akhtar, Ali, and Sadaqat in (2011) who argued that Murabha agreement is truly uncertain and cannot be blocked by using the techniques which will more expected to increase the compassion of risk. High risk awareness may be a sign of little degree of dynamic risk management due to the inattentive of risk control, concluded internal methods and control, specifically in the case of operational risk (Nazir, Daniel, \& Nawaz, 2012). The levels of risks faced by Islamic banks are found to be significantly higher than those faced by conventional banks. Similarly, country, liquidity, and operational, residual, and settlement risks are found to be higher in Islamic banks than in conventional banks. (Hussain \& Al-Ajmi, 2012). This suggests that the environment within which the bank functions is an important reflection for a credit risk management system to be successful.

\section{Conclusions}

In order to address the issue discussed in introduction, that Islamic banking is growingly rapidly, a comprehensive literature has been reviewed. On the basis of the reviewed literature it is concluded that the part of Islamic banking industry has improved its profits. Similarly, the literature has shown that Islamic banks have managed to enhance their profitability. Conventional banking is facing several issues but yet the banks are following conventional banking. Islamic banking in Pakistan is growing but at a slower pace (Faisal, Shabbir, Javed, \& Shabbir, 2016; Iqbal, Ali, Shabbir, \& Saleem, 2410; Shariff, Shabbir, Shukri, \& Bakar, 2018; Shabbir, 2009; Shabbir, Shariff, \& Shahzad, 2016; Shabbir, Shariff, Yusof, Salman, \& Hafeez, 2018). Despite the fact that in the recent years almost all the banks have started Islamic banking but the volume of Islamic banking in Pakistan is very low and its growth rate is also slow. Almost all the banks regardless national or international have started Islamic banking. It has been observed that the major problem of IBs is the liquidity problem, and due to Shariah Advisory Board and lack of well-trained human resource in Islamic Banks and relatively less products as compared to conventional commercial banks, but still apart from all these issues (Siddique, 2003), Islamic banking is getting popularity day by day but yet the growth rate is slow. It has been seen that Islamic banking has maintained the consistency in growth of both market share and 
profitability, as per current political situation of country researchers has observed that Islamic banking institutions might suffer, due to more liquidity and less investment but still, IBs maintain the profitability and the investment has increased up to $2.3 \%$ which results in $42 \%$ growth in profit of whole IBs. Regarding the lending structure it has been observed that Islamic banking follows Islamic modes of financing where as conventional banks follow purely interest based financing structure. It has been observed that Islamic banking is more prone to risk as compared to conventional banking. The basis reason is that the lending system in Islamic banking is based on profit and loss sharing, whereas, in conventional banking it is purely based on interest and a fixed interest is charged rather than going for any Mudarba or Musharika. There is no harm in saying that Islamic principles, can manage the financial crises and eliminate poverty which is the hot issue of every country including Pakistan, but in order to bring this dynamic change, efforts are need to be done at Government level in order to control these crises.

\section{References}

[1] Abdul-Majid, M., Saal, D. S., \& Battisti, G. (2010). Efficiency in islamic and conventional banking: an international comparison. Journal of Productivity Analysis, 34(1), 25-43.

[2] Ahmad, A., Malik, M. I., \& Humayoun, A. A. (2010). Banking developments in Pakistan: A journey from conventional to islamic banking. European Journal of Social Sciences, 17(1), 12-17.

[3] Ake, C. (1975). A definition of polictical stablity. Comparative Politics, 4(3), 133-156.

[4] Akhtar, M. F., Ali, K., \& Sadaqat, S. (2011). Liquidity risk management. Interdisciplinary Journal of Research in Business, 5(2), 78-102.

[5] Akhter, S. (2008). Islamic Banking. Karachi: Institute of Bankers.

[6] Ali, M. A. (2014). Evolution \& development of islamic banking The case of Pakistan. European Journal of Islamic Finance, 1, 1-6. doi:http://dx.doi.org/10.13135/2421-2172/777

[7] Aliyu, S., \& Yusof, R. M. (2016). profitability and cost efficiency of islamic banks: A panned analysis of some selected countries. International Journal of Economics and Financial Issues, 6(4), 17361743.

[8] Ansari, S., \& Rehman, A. (2013). Financial performance of islamic and conventional banks in Pakistan. 8th International Conference on Islamic Economics and Finance, 6(3), 445-486.

[9] Ariss, R. T. (2010). Competitive conditions in Islamic and conventional banking: A global perspective. Review of Financial Economics, 19(3), 101-108. doi:10.1016/j.rfe.2010.03.002

[10] Azmi, F. B. (2013). An empirical analysis of the relationship between GDP and unemployment, interest rate and government spending. Interest Rate and Government Spending, 89-112. doi:http://dx.doi.org/10.2139/ssrn.2276817

[11] Beck, T., Demirgüç-Kunt, A., \& Merrouche, O. (2013). Islamic vs. conventional banking: Business model, efficiency and stability. Journal of Banking \& Finance, 37(2), 433-447. doi:10.1016/j.jbankfin.2012.09.016

[12] Dietsch, M., \& Lozano-Vivas, A. (2000). How the environment determines banking efficiency: A comparison between French and Spanish industries. Journal of Banking \& Finance(24), 985-1004. doi:10.1016/S0378-4266(99)00115-6

[13] Faisal, M., Shabbir, M. S., Javed, S., \& Shabbir, M. F. (2016) Measuring Service Quality and customer satisfaction in Pakistan: Evidence Based on Carter Model. International Business Management.

[14] Gafoor, A. A. (1995). Interest Free Commercial Banking (Vol. chapter\#5).

[15] Hong, H., \& Yogo, M. (2012). What does futures market interes tell us about the macroeconomy and asset prices? Journal of Financial Economics, 105(3), 473-490. doi:10.1016/j.jfineco.2012.04.005

[16] Hussain, H. A., \& Al-Ajmi, J. (2012). Risk management practices of conventional and Islamic banks in Bahrain. The Journal of Risk Finance, 13(3), 215-239. doi:10.1108/15265941211229244

[17] Iqbal, M. J., Ali, G., Shabbir, M. S., Director, M., \& Saleem, M. (2410). the Effect of Devotee-Based Brand Equity on Religious Events. Paradigms: A Research Journal of Commerce, 10(1), $23-$ 43.
[18] Islam, J. U., \& Rahman, Z. (2017). Awareness and willingness towards Islamic banking among Muslims: An Indian perspective. International Journal of Islamic and Middle Eastern Finance and Management, 10(1), 92-101. doi: https://doi.org/10.1108/IMEFM01-2016-0017

[19] Jalbani, A. A., \& Shaikh, S. A. (2009). Risk management in islamic and conventional banks: A differential analysis. Journal of Independent Studies and Research, 7(2), 67-70.

[20] Lal, P., \& Snehal, S. (2008). Islamic Banking and its Application in the Current Economy. Review on Islamic Banking, 134-149.

[21] Lee, K.-h., \& Ullah, S. (2008). Inter-bank cooperation between islamic and conventional-The case of Pakistan. International Review of Business Research Papers, 4, 1-26.

[22] Mahmood, M. N. (2007). Economic Survey of Pakistan. Islamabad: Government of Pakistan.

[23] Miah, M. D., \& Uddin, H. (2017). Efficiency and stability: A comparative study between islamic and conventional banks in GCC countries. Future Business Journal, 3(2), 172-185. doi:10.1016/j.fbj.2017.11.001

[24] Mobarek, A., \& Kalonov, A. (2013). Comparative performance analysis between conventional and islamic banks. Applied Economics, 5(1), 125-162.

[25] Nazir, M. S., Daniel, A., \& Nawaz, M. M. (2012). Risk management practices: A comparison of conventional and islamic banks in Pakistan. American Journal of Scientific Research, 2(2), 433-452.

[26] Shatilova L.M., Borisova V.V., Kasatkina O.A. (2018). Representation of the linguistic and cultural concept "lie" in the French and Russian language picture of the world, 34(85), Pp. 194-212.

[27] 2 Bakhyt S., Kalimbetov B., Khabibullayev Z. (2018). Possibilities of Mathematical Problems in Logical Thinking, Development of Secondary Education Pupils, 34(85), P.p. 321-338.Sabir, R. I., Akhtar, N., Ghafoor, O., \& Hafeez, I. (2014). Difference between islamic banks and commercial banks performence in Pakistan. International Review of Management and Business Research, 3(4), 48-59.

[28] Samad, A. (2004). Performance of interest-free Islamic banks visà-vis Interest-based conventional banks of Bahrain. International Journal of Economics, Management and Accounting, 12(2).

[29] Shabbir, M. S. (2009). SUPPORTIVE LEARNING ENVIRONMENT - A BASIC INGREDIENT OF LEARNING ORGANIZATION. In Proceedings 2nd CBRC, Lahore, Pakistan November 14, 2009.

[30] u Van TUAN Communicative Competence of the Fourth Year College Students: Basis for proposed English Language Program, Astra Salvensis, Supplement No. 2, 2017, p. 45

[31] [1] Irina MALGANOVA, Andrey ERMAKOV, Development of heating Devices from Polypropylene, Astra Salvensis, Supplement No. 2, 2017, p. 93

[32] Jana Arturovna KLAAS, Thomas Arturovich KLAAS Econometric Model of Early Diagnosis of a Credit Institution Bankruptcy Risk, Astra Salvensis, Supplement No. 2/2017, p. 107.

[33] Gulnaz Mavletzyanovna GALEEVA, Olga Aleksandrovna AKTASHEVA Forecasting the Dynamics of Foreign Direct Investment in the Russian Economy, Astra Salvensis, Supplement No. 2/2017, p. 137

[34] Kamil Maratovich ARSLANOV, Artur Ilfarovich KHABIROV About the Weak Party of the Loan Contract, Astra Salvensis, Supplement No. 2/2017, p. 323.

[35] Ullah, N. (2016). Influencing factors of profitability on the banking industry : A case study of GCC countries. Munich Personal RePEc Archive, 1-21 